\title{
Responses to Religious Diversity in Spain: Hospitals and Prisons from a Comparative Perspective
}

\author{
Julia Martínez-Ariño / Mar Griera
}

The increase in religious diversity is an indisputably clear trend in most European countries. This transformation has given rise to challenges to the ways in which states and secular institutions have traditionally provided their services. Our research is embedded in academic debates about the responses of secular state-run institutions to the religious diversification of the population. We compare two different institutional settings: prisons and hospitals. Drawing on ethnographic research conducted in eight prisons and six hospitals in two regions in Spain, we show that there is no single nationwide policy that addresses religious diversity in public institutions. Rather we suggest that institutionspecific characteristics along with context-related factors help explain how these two types of institutions respond differently to religious diversity. This shows how national regimes of state secularism are deployed in differing directions, depending on various organisational and contextual factors.

Julia Martínez-Ariño is a postdoctoral fellow at the Max Planck Institute for the Study of Religious and Ethnic Diversity (Göttingen, Germany) and research associate of the research unit ISOR (dir. Mar Griera) and the Religion and Diversity project (dir. Lori Beaman). She received her PhD in Sociology from the Universitat Autònoma de Barcelona in 2012, where she worked as a doctoral student and researcher. Julia has been a postdoctoral fellow at the Université de Montréal and a visiting scholar at the Universität Wien and the École des Hautes Études en Sciences Sociales. Her main research interests are the contemporary Jewish communities, the accommodation of religious diversity in public institutions and the involvement of religious organizations in the local governance of diversity.

Mar Griera is Associate Professor of Sociology at the Universitat Autònoma de Barcelona (UAB). She is also the director of the research unit ISOR (Investigacions en Sociologia de la Religió) based at the Sociology Department of the UAB. She teaches sociology of religion and contemporary sociological theory. Her research interests lie at the intersection of religion, identity, politics and memory. She is also a research associate at the Centre de Sociologie des Religions et d'Éthique Sociale of the Université Marc Bloch (Strasbourg, France). She has been a visiting fellow at Exeter University and at the Institute on Culture, Religion and World Affairs (Boston University) among others. 


\section{Introduction}

Secular public hospitals have a short history in Spain. A century ago most of the existing hospitals belonged to the Catholic Church. Religious orders were the owners of hospital facilities and were in charge of running them (Ausín 2007). The democratisation, modernisation and secularisation of the country in the last quarter of the twentieth century changed this situation. The constitutional disestablishment of the Catholic Church in Spain in 1978 and the adoption of the 7/1980 Religious Freedom Act had significant consequences for the presence and role of religion in public institutions. At present, the Catholic Church has a vestigial presence in public hospitals and the religious origins of the Spanish health care system are being progressively erased. Similarly, prisons have also become far more secularised institutions in the last few decades. Catholic morality no longer works as the ethical framework in regulating inmates' behaviour and the role of Catholic chaplains in prisons has diminished considerably (MartínezAriño et al. 2015). Moreover, chaplains are no longer considered civil servants, as they were in the past. In essence, the impact of the secularisation process on Spanish public institutions is evident nowadays.

However, religion is not completely absent from these institutions, despite in many cases remaining invisible to the public gaze (Cadge / Konieczny 2014). On the one hand, the historical influence of religion has not been removed completely from the current functioning of Spanish public hospitals and prisons. One can still detect several traces of the former Catholic regime, which become apparent in the material spaces and routines of the institutions. On the other hand, the fact that around $70 \%$ of the population, according to survey data (CIS 2015), still consider themselves Catholic in contemporary Spain inevitably carves out a role for religion in public institutions. This is especially relevant for those institutions, such as prisons and hospitals, where individuals are not able to carry out their religious practices by themselves. Spanish legislation requires public institutions to grant religious freedom to everyone and to provide the necessary conditions for the real exercise of such. In parallel, the substantial diversification of the Spanish religious landscape in recent years has given impetus and significant visibility to religion in public institutions.

The increase in migration-led religious diversity has given rise to new challenges for the functioning of public institutions. The growing visibility and increasing claims-making activism of religious minorities foster a reconfiguration of the traditional patterns regulating religion in institutional contexts. The governance of religious diversity has become a matter of concern for public authorities in recent years, and the complexity of the new situation crystallises and becomes apparent in the everyday context of these organisations. This new reality unsettles previous formal and informal arrangements and agreements on the role of religion in hospitals and prisons, and raises the issue of religion and the accommodation of minorities. 
The role of religion in public institutions is a matter of concern not only for public authorities but also for academics. Following James Beckford and Sophie Gilliat-Ray's (1998) pioneering work on religion in prisons in England and Wales, numerous research projects across Europe and North America have focused on analysing the role of religion in public institutions (Cadge 2012; Furseth 2003; García-Romeral et al. 2007; Rostaing et al. 2014). As Irene Becci, among others, notes (2012), public institutions stand as crucial sites in the study of the relation between religion and the state. By emphasising different analytical dimensions and thematic focuses, these studies evince the continuity of dividing lines between majority churches and minority religious groups (Becci / Knobel 2014; Sheik et al. 2004), the institutionalisation of Muslim chaplaincies in various institutions (Gilliat-Ray 2010; Michalowski 2015), the various strategies of interfaith chaplains in secular contexts (Cadge / Sigalow 2013) and the influences of the institution's characteristics on the religiosity of inmates (Becci 2012).

Nevertheless, despite significant growth in this body of scholarship, the focus has mainly been on single institutions and cross-country comparisons (Beckford / Cairns 2015). Apart from a few exceptions (Furseth 2003; Todd 2015; Bertossi and Bowen 2014), there has been little cross-institutional comparative research. Our article contributes to this underdeveloped area in the literature by analysing and explaining the similarities and differences between hospitals and prisons in dealing with the increasing religious diversification of their target populations in Spain.

The point of departure of this cross-institutional comparison is the empirical data gathered in the framework of a four-year research project entitled "GEDIVER-IN: The management of religious diversity in prisons and hospitals in Spain" funded by the Spanish National Research Program. It consists of a qualitative multiple-case study conducted in Spain between 2011 and 2014. We conducted fieldwork in eight prisons and six hospitals. Adopting a qualitative approach based on interviews, participant observations in the religious services, shadowing of chaplains during their visits, and document analysis, we were able to capture how religious diversity is negotiated and handled on a daily basis in these two institutions. In total we conducted 100 interviews with state officials, civil servants, institutions' staff, religious actors, and faith-based NGOs.

The article demonstrates that there are significant differences in the responses provided by hospitals and prisons to the growing religious diversification of their populations (Griera / Martínez-Ariño 2014). We examine the factors behind these changes and argue that there is no straightforward institutional response to religious diversity, but rather complex and non-linear processes of adjustment.

The article is structured as follows: We start by presenting some of the common attributes and specificities of the two institutions we compare in our study, and their implications for the accommodation of religious diversity. We continue by detailing some of the main institutional transformations that hospitals and prisons have adopted to respond to religious diversity in Spain. Following this we account 
for the cross-institutional similarities and differences by pinpointing some of the most relevant national and institution-specific factors, which may explain the commonalities and disparities. We close the article with some general conclusions.

\section{Researching religion in hospitals and prisons}

This article adopts a meso-level perspective on the governance of religious diversity that focuses on the institutional level. As Cadge and Konieczny (2014, p. 554) argue, an "admixture of secularisation and religious vitality appears in organisational contexts", thus making them key settings for the study of the governance of religious diversity in so-called secular states. Our research compares two specific institutional settings: hospitals and prisons. These are two public institutions in which citizens encounter the state (Bowen et al. 2014). Additionally they are both interfaces between the requirements of the secular state, on the one hand, and increasing religious diversity on the other.

Historically, both have been considered total institutions (Goffman 1961a). Yet this does not mean that they are completely separate and isolated from the larger social environment (Cressey 1961) ${ }^{1}$. In this article we adopt Street and Coleman's (2012) and Sargent and Erikson's (2014) position, which emphasises that hospitals (and we add prisons here) have the capacity to be "simultaneously bounded and permeable" (Street / Coleman 2012, p. 4). They are affected and shaped by the wider community; and hierarchies, inequalities and conflict are reflected and reproduced therein. However, simultaneously, they possess some particularities that make them unique spaces, understood as "configurations of material and discursive practices" (Street / Coleman 2012, p. 10). Thus, parallel to the social and cultural processes that surround them (van der Geest / Finkler 2004), their specific characteristics and ordering systems cannot be overlooked. This involves careful consideration of not only their official organisation, but also of those organisational aspects that are unofficial and therefore more difficult to change, as the latter are difficult even to state (Cressey 1961). These are of particular importance when they become "organizational routines" (Zucker 1987, p. 456). Along similar lines, Bertossi and Bowen (2014), in their chapter on Islam and Muslims in schools and hospitals in France, compare how institutional actors draw on "practical schemas" - understood as "complexes of ideas, norms, values, and emotions [...] not reducible to a national model or ideology" (Bowen et al. 2014, p. 3) - to guide their actions.

Despite these common qualities, these institutions have undergone substantial transformations and evolved along quite different lines, which have resulted in

1 In this regard, hospital and prison visits have been a common practice since the mideighteenth century, showing the permeability of the institutions' walls (Mooney / Reinarz 2009). 
different institutional opportunity structures for the accommodation of religious diversity. According to Blau and Scott's (2003) typology of organisations based on the criteria of who the prime beneficiary of the institution is, hospitals are "service organizations" that historically "had their beginnings in charitable and religious institutions that looked after the poor. Toward the end of the nineteenth century, the hospital became a recognised establishment and symbol of modernity [...] with the incorporation of biomedicine as a scientific practice" (Finkler / Hunter / Iedema 2008, p. 246). Through this transition hospitals have become "impersonal institutions manned by experts" (Finkler / Hunter / Iedema 2008, p. 246) whose main duty is healing. Despite being hospitalised, patients actually maintain contact with their families and other social institutions (van der Geest / Finkler 2004). The greater permeability (Goffman 1961b) of hospitals as compared to prisons also leaves more room for the emergence of "institutional entrepreneurs", who use their personal resources to introduce changes in the institutional structure (DiMaggio 1988).

Prisons are considered "commonwealth organizations" (Blau / Scott 2003), in that they benefit the public at large, though usually at the expense - in the form of exclusion - of those whom the organisation hosts. Even if there has been a shift towards prioritising prisoners' rehabilitation (resembling service organisations) (Cid / Martí 2011), keeping outcasts away from the rest of the society remains the central goal. Prisons epitomise Goffman's (1961a) notion of total institutions, controlling the entire life of inmates, particularly in terms of time, space, bodies and social relations. This special situation has significant implications for the practice of religion, which adopts particular forms, meanings and roles in the context of the prison (Becci 2012). The institution is the main guarantor of the right to religious freedom and equality, as recognised by most constitutions in liberal democracies. Thus it is the one primarily responsible for providing the means and conditions for their exercise by inmates, thereby leaving little option for other actors to act autonomously. Also, in contrast to hospitals, the division between public and private lives and space in prisons is almost non-existent, which again places the institution at the centre of every activity.

In the particular case of Spain, hospitals and prisons also differ in their specific characteristics. While the administration of the health care system is decentralised - with hospitals being regulated at the regional level - the administration of prisons, except in the region of Catalonia, is centralised. Moreover, hospitals within each region enjoy greater room for manoeuvre in the organisation of the services they provide, leading to less standardised managerial styles. In addition hospitals have also undergone deeper processes of privatisation and outsourcing of service provision (Acerete et al. 2011; Cabiedes / Guillén 2001), while prisons have remained genuinely public institutions, with fewer services being privatised. All of these particularities shape different opportunity structures that condition the way in which religious diversity is governed (Michalowski 2010). 
Hospitals and prisons also differ in the religious diversity they face. According to the official statistics for January 2015 (INE 2015; SGIP 2015) non-Spanish citizens are overrepresented in Spanish prisons, accounting for $29.7 \%$ of the imprisoned population, as compared to $10.1 \%$ of the general population. This, then, also means a highly diverse population in religious terms (Gallego et al. 2010). By contrast, hospitals attend to a much more homogeneous population as regards religion, mainly because they serve, on average, a much older population that is mainly Spanish and self-identifies as Catholic. Over $44 \%$ of the hospitalizations in public hospitals in 2013 were of people over 65 years old, who also spend longer periods hospitalised (SNS 2015). The profile of the populations both institutions cater to is thus significantly different, which - added to the fact that the average stay in hospitals is considerably shorter than that in prisons presents different challenges for the functioning of the respective organisations.

\section{Comparing institutional responses to religious diversity in Spain}

Religion has been relegated to the background of public institutions that define themselves as secular (Martínez-Ariño et al. 2015). This is discernible both in hospitals and prisons: Catholic chaplains have lost their status as civil servants, religious services are now provided only on request, and Catholic symbols have mainly been removed. This has run parallel to a wider process of secularisation as well as growing religious diversification in Spanish society (Pérez-Agote 2012).

Growing religious diversity has also entailed the increasing presence of "visiting ministers" (Gilliat-Ray 2010) and religious volunteers for minority religions in both settings. Yet, unlike the situations in the UK (Gilliat-Ray 2005), the US (Sullivan 2014) and Canada (Beckford / Cairns 2015), where inter-faith chaplaincies are more common, religious care provision in Spain is organised around faith-specific chaplaincies (Michalowski 2015). However, a clarification should be made before moving on: when we refer to chaplaincy here, we are not always referring necessarily to an organised and institutionalised service, as is the case with Catholicism. Religious minorities' visiting representatives are very rarely exclusively dedicated to working in a particular institution. Most of the time they have jobs in the regular job market or are in charge of their religious communities while simultaneously providing religious care in state-run institutions.

At a more symbolic and discursive level, in contrast to what has occurred in other countries like France or Canada - which have strong national narratives of laïcité and multiculturalism, and interculturalism respectively - much less public debate about the public expression of religion has taken place in Spain. Apart from a few exceptions related to the ban on the wearing of the burqa in municipal facilities (Burchardt et al. 2014) and the never-ending debate on religious education in public schools, religious diversity issues rarely arise in the Spanish public 
sphere as vividly as they do in those of the other two countries. Likewise, public commissions aimed at discussing the public role of religion in society (i. e. the Stasi and Bouchard-Taylor Commissions) have not been instituted in Spain. Nor have judicial politics gained ground in this area.

However, the lack of major public controversies over this issue has not hindered the incorporation of religious affairs into the policy agenda of the Spanish government. From 2004 onwards the Spanish government has developed an active policy aimed at governing religious diversity by fostering an accommodating approach towards religious minorities (Astor 2015). The heart of this approach has been the creation of a funding program for religious minority communities, the building of multi-faith chapels in public institutions, and the publication of non-binding guidelines promoting the accommodation of religious diversity. In this regard, the Spanish government published a guide on the accommodation of religious diversity in hospitals providing information on the doctrinal requirements of religious confessions (Catholic Church, Protestantism, Islam, Judaism, Jehovah's Witnesses, Orthodox Churches, the Church of Jesus Christ of the Latter-day Saints and Buddhists), describing the legal framework and facilitating practical recommendations for the accommodation of religious diversity. The Catalan Government has promoted the publication of a similar booklet with guidelines, in addition to one for prisons.

Yet, in spite of this shared context, significant differences can also be observed in the approaches of hospitals and prisons to religion and religious diversity. Prisons are, through the introduction of more organisational changes, far more active in responding to religious diversity than hospitals. The schemas used to justify the way religious diversity is dealt with in prisons and hospitals also differ. Two metaphors serve to illustrate these differences: the hospital as an aseptic space where the biological body is to be cured and the prison as a holey site where the social body (Scheper-Hughes / Lock 1987) is to be restored.

\section{The marginal position of religion in the aseptic hospital}

When one thinks of modern hospitals, one of the first ideas that comes to one's mind is the asepsis that characterises such spaces. Personnel wear special attire, including surgical caps, to ensure hygiene. Medical instruments are sterilised, and shared spaces and rooms are constantly cleaned, with bedding being changed at least once a day. The objective is to avoid contamination and keep the risk of infections to a minimum. In more figurative terms the supposedly neutral body of biomedical knowledge that informs these institutions reinforces this image of hospitals as being aseptic places. The biomedical approach is considered to be free from any ideological influence (Beagan 2000) and thus "clean" and "pure". The purpose of hospitals is defined as healing the individual biological body (ScheperHughes / Lock 1987) from the perspective of the scientific biomedical model. The 
development of the biopsychosocial model (Borrell-Carrió et al. 2004) notwithstanding, the predominant paradigm in medical settings is still that of the biomedical, which adopts a materialist understanding of the body and presents itself as being neutral and rational. For modern biomedicine "body and self are understood as distinct and separable entities" (Scheper-Hughes / Lock 1987, p. 21) and thus curing the "palpable body" (Scheper-Hughes / Lock 1987, p. 9) is considered the domain of science, while healing the soul is considered the domain of theology.

All of these notions of the sterile and sanitised space in hospitals and of the hegemony of the "neutral" of biomedical knowledge also apply to the way in which the presence of religion is perceived and managed in these institutions. As Street and Coleman (2012, p. 11) note, "differences between biomedical and nonbiomedical space are established internally through discursive and spatial practices". In Spanish public hospitals these practices and discourses place religion in a vestigial position, where it is seen as something supplementary and extrinsic to public healthcare. In this regard one official of the health system affirmed: "As I said, we try to assure high-quality care for every citizen, but nothing else. Spiritual care is not part of this public health service" (Hosp1). Analysis of the interviews reveals that in some circumstances religion is even considered a "contaminating" agent that might disrupt the correct functioning of the hospital, particularly regarding the interference of religious prescriptions in the decision-making of patients.

From the democratic transition to the present day, religion in Spanish hospitals has progressively been removed spatially as well as functionally. The spatial and visual presence of religion is minimal and well delimited, and mainly restricted to the spaces of the chaplain's office and the chapel. In some cases the latter occupies a quite central and visible position, but in a growing number it is located in concealed basements and other nooks in the complex spatial structure and configuration of modern hospitals. Religious images and symbols are hardly to be found in corridors, waiting rooms or other common spaces. Information about chaplaincy occupies the minimum space in hospitalisation leaflets and notice boards. Signs announcing the availability of chaplaincy services have even been, as reported by our interviewees, removed by healthcare staff on some occasions. Legally, religious care is the patient's right independent of his/her religious affiliation. Moreover, in the case of Muslims, Jews and Protestants, this right is explicitly enshrined in the cooperation agreements that these denominations signed with the Spanish government in 1992. However, their implementation has been weak and inconsistent.

We have identified two main legal drivers behind the displacement of the role of religion within Spanish public hospitals. First, the democratic transition and the legislative changes that it involved in areas like religious freedom and public health contributed to a process of de-confessionalisation in public hospitals. The role of the Catholic Church was confined to strictly religious matters and its 
former monopolistic and hegemonic position was challenged. The Catholic Church did not resist the secularisation measures and conformed by adapting its position to the democratic rules of the game. However, several legislative agreements and by-laws granted the Catholic Church the right to maintain a chapel in every hospital, the allocation of funding for chaplaincies, and office space in hospitals. The Catholic Church was formally disestablished but still maintains a prominent position in religious matters, a situation that is especially apparent when comparing it with that of other religious groups, which have formally recognised but unimplemented rights to religious freedom and religious care (there is neither funding nor implementation procedures).

The second major legal change affecting the presence of religion in the public healthcare system is the development and implementation of new medical ethics paradigms. The patient autonomy model based on the principle that patients have the right to make decisions about their medical care, together with legal advances in data protection, has affected religious affairs indirectly by drawing clearer boundaries between the religious and medical fields. Today, the role that religion and religious ideas and actors play in the making of medical decisions is restricted and formally delimited, especially through the legal granting of the right to patient autonomy. Currently, Spanish hospitals are increasingly adopting a rights-based strategy that manifests itself in consent forms, advance directives and specific protocols regulating the procedures and steps to follow in controversial situations. Yet, the rationale behind all these measures is also delimiting and reinforcing the boundaries between the medical and non-medical fields and protecting medical staff from any legal action taken against them. Thus, while the discourse on the patient's right to decide on medical treatments overtly holds sway, be it driven by religious reasons or others, and there is a commitment to respecting the patient's decisions, other motives - such as avoiding legal trouble and protecting "epistemic authority" (Lamont / Molnár 2002, p. 179) - cannot be underestimated. Jehovah's Witnesses have welcomed the regulations on the autonomy of patients since they facilitate their refusal of blood transfusions. In contrast, the Catholic Church has received these changes ambivalently because they have indirectly restricted the role of Catholic actors in hospitals. At present chaplains are no longer allowed to access hospital records to know which patients are hospitalised and who may require their presence and support. Along the same lines, chaplains' freedom of movement has been restricted and they are, in theory, no longer allowed to enter hospital rooms unless requested to by a patient. This limitation has increased the number of complaints by chaplains, who perceive it as an obstacle to reaching patients. As one Catholic chaplain stated, "Patients are not informed of the service and we are not able to inform them directly. So there are many unattended patients. In many cases the hospital only informs us when patients are dying" (Hosp2).

Yet ethnographic fieldwork has made evident that there is a significant gap between what is legally prescribed and what actually occurs in many hospitals. 
Historical routines and entrenched personal loyalties sometimes favour the rules not being applied to Catholic chaplains with the same degree of strictness that they are to representatives of religious minorities. Interviews of medical staff and minority ministers show that, when considering religious actors' visits and counselling of patients, the distinction between "proselitysm" and "genuine human interest" depends to a great extent on the denomination of the actor concerned. In general terms Catholic actors are allowed wide latitude. The following quotation, by the hospital manager in one of the largest hospitals in Spain, is illustrative of this. She noted that "The priest has the habit of going through all the rooms" and added: "but he is a holy man, he is really a good man. He provides spiritual care to everyone, whether they are Muslims or Chinese or. [...] This care is often related to covering social needs, right? Lack of resources, being alone, having no family. [...] The priest treats them all" (Hosp3). Catholic actors are perceived as benign and their non-observance of the right to privacy is viewed as a minor fault.

This wide latitude with regard to Catholic chaplains is even more noticeable when analysing their role in palliative care units. The presence of Catholic chaplains there is accepted and unquestioned more than in any other hospital unit. The more individualised patient-oriented approach adopted in these units results in a greater awareness of religious and spiritual needs. However, it should not go unnoticed that this more tolerant attitude towards religion is also a consequence of the fact that medicine reaches its limits in such units. Medical staff do not need to do boundary work since the biomedical paradigm has already lost the game.

In this context religious minorities are frequently regarded with suspicion and distrust either because of their supposedly proselytising activity or because of the burdens they can represent for "normal" medical practice. As one of the Protestant chaplains stated: "Catholic chaplains walk all around the hospital but if we do that we are accused of proselytism" (Hosp4).

Therefore, while we witness a formal and explicit displacement of religion in hospitals, we also observe that Catholic actors still hold a significant position. This becomes especially evident in comparative terms. Thus the comparatively privileged position of the representatives of the Catholic Church, who enjoy significant benefits - such as public funding, free vouchers for hospital canteens, inhouse communication devices, but also better personal treatment - cannot be equated with that of religious minorities. The weight of the historical Catholic legacy still surreptitiously permeates the "institutional habitus" (Bowen et al. 2014, p. 11) of medical institutions in Spain.

The fieldwork has also revealed the recent introduction of some minor institutional innovations and individual arrangements in some public hospitals, which dilutes the "laicist" nature of the aseptic approach. All of these innovations have one characteristic in common: they are put into practice by altruistic institutional entrepreneurs willing to improve the situation of religious minorities. We refer to innovations such as the creation and distribution of a list of contact details of religious minority leaders in the area, the promotion of inclusive multi- 
faith chapels and the institutionalisation and formal accreditation of religious minority chaplains in hospitals. Most of the entrepreneurs we came across in the fieldwork were nurses and doctors who were personally involved with religious issues, whether as members themselves of a religious minority or being especially sensitive to religious issues. In some cases, the Catholic chaplain can become their ally - playing a similar role to that which Beckford (2007) called "brokerage" in UK prisons. In other cases the Catholic Church is indifferent or even openly hostile towards these minorities.

In summary, the way religion and religious diversity in particular are being handled in Spanish hospitals can be characterised by the drawing of a sharp distinction between the field of clinical care, which is the formal mission of such institutions, and that of religion and spiritual care, which is left to a more private space - that of the hospital room. The responses to religious diversity in hospitals in Spain have to be understood in light of the conception of the hospital as an aseptic space, both in material terms as well as that of the "neutrality" of scientific knowledge, which is used to account for the relatively marginal place occupied by religion in hospitals. However, this portrayal of the place of religion in public hospitals in Spain should not lead to an oversimplification of how things actually work. Nuances must be highlighted to shed light on the complex nature of the arrangements made by hospitals to manage religious diversity.

\section{Prisons: the gap-filling role of religion in the holey total institution}

Prisons, the paradigmatic example of total institutions, are characterised by highly bureaucratised and rigid formal procedures. Every person, movement, object and space is controlled. No door opens before the previous one has closed. Schedules are highly standardised and any deviation that may occur destabilises the organisational rhythms and dynamics. Tasks are also strictly differentiated and divided among the different strata of the staff. Different from hospitals, which aim to heal the individual biological body, prisons target the social body (ScheperHughes / Lock 1987), understood symbolically as a metaphor for the functioning of society and social relations. The objective is to control and punish, but also to correct those behaviours that are considered to be dysfunctional or malfunctional for society. Thus, the production of normal social bodies is one of the main tasks of prisons. In this case, then, it is the social body and not the biological one that must be "cured" and re-socialised. To accomplish this, discipline and order are seen as both means and milestones by the institution. Yet, despite the highly structured and structuring nature of prisons, they are at the same time muddled spaces. The distinction between public and private spaces is rather fine, resulting in the unlikelihood of finding private and quiet spaces. As a result, private and public lives are interwoven and subject to the operating rules and procedures of the institution. Due to insufficient resources, prisons are riddled with gaps that remain 
uncovered. The scarcity of means obliges imaginative adaptation, leading to situations such as the very different uses of spaces from their initial purpose. Resource shortage also defines the link between the inside and the outside world, as exemplified by the scarcity of social services to facilitate the transition from incarceration to a return to life in open society. The intermediary role played by civil society organisations providing shelter and fellowship at this point is crucial. These organisations help to bridge the gaps left by an institution that resembles a sieve somewhat.

All of these aspects of the penitentiary today have implications and provide differential opportunity structures for the ways in which religion and religious diversity are understood and managed. Clearly different from the view of the health official over the non-commitment of the hospital to the provision of religious care, one official from the prison system acknowledges religion as only one service out of many provided by the institution: "Religious care is just one of a number other services that the penitentiary institution provides to its population while it is incarcerated" (Pris1). Religion is seen somehow as part of the institution even if prisons, like hospitals, have been secularised (Griera / MartínezAriño 2014; Martínez-Ariño et al. 2015). Thus it is easier to find examples of the institutional arrangements made by prisons to accommodate religious diversity than ones by hospitals. As a civil servant in the penitentiary administration told us, the existence of agreements with some religious groups is crucial in establishing the conditions for the fulfilment of chaplaincy provision, such as the supply of infrastructures and the setting up of spaces for religious purposes, even if space is not exactly available in abundance. However, he insists on making clear that these efforts to respond to religious diversity are different from "building a mosque inside the prison" (Pris2), which he clearly perceives as inappropriate. In a sense, the fact that the prison administration has moved forward much more than hospitals towards the deployment of the agreements between the state and some religious groups through specific regulations has had consequences for the responses to the religious diversification of the population. The existence of more precise regulations for prisons creates the framework for more direct and defined interventions to address people's religious requests.

Nonetheless, this does not mean that the practice of religion and all religious practices are allowed complete freedom within Spanish prisons. Restrictions take many different forms, as also reported by Beckford (2013) in his research in England and Wales. Both in Beckford's research and in that which we conducted in Spain, limits on the number of people that can gather for worship were reported. We also found that access to certain units, such as high security ones, is often restricted for religious actors. Yet these impediments seem to affect various religious groups differently. While major Catholic celebrations such as Christmas Mass and theatrical productions of the Easter Passion can easily bring together dozens of inmates in several Spanish prisons, the gathering of numerous inmates from other religious traditions, especially Islam, is regarded with suspicion and 
usually more strictly monitored through attendance lists. Not coincidentally the collective Muslim prayer on Friday is often discouraged or impeded, while individual prayer is favoured. Hindrances to religious practice in prisons are mainly justified by the "phantom of "security" (Goffman 1961b, Martos et al. 2009) and all-encompassing in-house rules. As one prison director told us, they do not care about inmates' level of participation in religious activities. For him, the issue is not whether a religious minister can persuade many inmates to come to his or her service, but rather the possibility that high turnout can involve security issues. In his words:

Participation in religious activities can have implications for us if they want to celebrate a community activity and they have a list with 500 inmates willing to participate in it. First the auditorium can only accommodate 100 people and also for security reasons that wouldn't be possible. But we try to facilitate things anyways and tell them to split the inmates into several celebrations. But this is just a matter of security, it has nothing to do with the faith they belong to. (Pris3)

Internal rules can also inhibit or restrict certain religious practices and symbols, as another prison manager explained to us when asked about the possibility for inmates to have religious symbols in their cells: "These are allowed, they can have whatever they want as long as they preserve order and respect the internal rules" (Pris1).

Religious communities play a manifold role in prisons. As also documented by Becci (2012) in Eastern German prisons, religious communities fulfil additional functions beyond their explicit role of providing religious counselling, celebrating religious services and offering moral support. On the one hand, religion fills in the gaps left by the institution and the welfare state in terms of social services. Examples of this are to be found in many activities and services, such as anti-drug programs, housing for periods of temporary release, accompaniment during cultural activities outside the prison and vocational training. During the fieldwork we encountered large numbers of civil society organisations, many linked to religious communities, providing their services in prison. They are included in a national coordinating body called the Penitentiary Social Council created in 2008 by the Ministry of the Interior, which also has local branches in each prison. In particular, the fact that prisons treat the social body, and thus need "integrative" elements, leads to an understanding of why the institution relies to such an extent on civil society organisations, and in particular religious groups. As one prison manager states, "the penitentiary institution is open to the religious sector as it has also been opened to third-sector entities and to every association willing to contribute to the life inside prisons" (Pris1). In Spain, the principal agent is the Catholic Church and related social and welfare organisations, which, according to one prison manager, play an integrative role both within the prison and also in mediating between it and the outside world. However, interestingly enough, the 
reputation of Protestant organisations has increased considerably in the Spanish prison system over the last few decades. The ability of Protestant NGOs to enrol inmates with drug addictions in rehabilitation programs has accorded them social recognition. As reported by one prison director, "Protestants play an important role in relation to those inmates who want to stop taking drugs. We are very grateful to them because they do interventions that couldn't be done otherwise" (Pris4). These communities also have shelters where some inmates can serve the last part of their sentence, something that would not be possible with only the resources of the prison system.

On the other hand, religion in prisons increases social harmony and enforces control. This is how prison managers and ground-level workers perceive religion in general, with the exception of Islam, which is often regarded with suspicion. The function of religion in the prison context is well expressed by one of the penitentiary officials we interviewed:

Those of us who know the prison world know that if the social atmosphere in the prison is good, it prevents many tensions and conflicts. [...] So if religious care helps to maintain a stable social climate, we civil servants make an effort to make that work well. [...] If that works well, the better the climate in prison, and that's one of the main aims one has in mind when putting on the uniform and entering the prison to work. (Pris4)

Beyond this abstract account, more concrete examples of how religion and religious actors, in particular Catholic chaplains, are instrumentalised by the institution for order and control purposes were found during the fieldwork. One Catholic chaplain told us that "sometimes prison directors have come to me saying, 'Look, we have this problem, please see what you can do to solve it'". More specifically this chaplain explained to us:

When gangs started to appear, the director of the prison called me before Mass some Sundays and told me, 'Hey, could you tell the inmates on Sunday that violence between them is not OK? I'm tired of it'. So I would use the sermon and indirectly tell them to stop. So I will always spread peace, but if the management requests me to do so, I will emphasise it even more. (Pris5)

Yet this controlling task is no longer the monopoly of the Catholic Church. The institution also uses strategically the ability of Protestant organisations to convince inmates of the power of God's Word to overcome the hardship of imprisonment. Two Protestant ministers told us that they perceive that the staff treat them very well because they bring peace and calm to the prison. In this task of keeping order, holistic spirituality and personal growth activities such as yoga, meditation and Reiki increasingly play a crucial role. These are also seen as helping improve the wellbeing of inmates and, as a consequence, the entire prison environment. However, in most of the cases where such activities are offered to 
inmates the institution itself - via some motivated professionals, namely social educators - is the organiser. These activities help to not only pacify the population but are also meant to "reform" inmates (Griera / Clot-Garrell 2015a; 2015b). This was clearly expressed by one of the Reiki teachers, who affirmed that: "The whole time we have been focusing on people who are physically ill or who have a problem, but in the prison you realise that the solution, the fact of being well, is an internal healing. This is where our technique works: leave the body alone if what is important is healing oneself spiritually" (Pris6). Here, as opposed to hospitals, where the boundaries between medical epistemologies and religious/spiritual epistemologies are sharply defined, secular and religious epistemologies intermingle to the extent that both share the task of curing the social body.

\section{Institutional opportunity structures and contextual factors}

Prisons and hospitals in Spain respond in both similar and different ways to the challenges presented by increasing religious diversity within their facilities. On the one hand, the main similarity between both institutions is their common policy based on a case-by-case logic to address the religious requirements of their target populations. The lack of a strong and dense normative nationwide narrative on religious diversity, such as multiculturalism, laïcité or interculturalism, as well as the limited legal activity and policy making in this domain at the national level, can account for the widespread adoption of such a pragmatic approach. The symbolic frames and discursive repertoires surrounding religious issues available for mobilisation by institutional actors, such as prison and hospital managers and workers, are generally restricted to generic references to the legal recognition of the right to religious freedom. This rights-based discourse can be found in both institutions. Therefore, the general narrative of institutional actors is that they are obliged to follow the Constitution by protecting the right to religious freedom recognised therein. An example of this can be found in the following quote by one high-ranking civil servant in the prison system: "I think that religion is: first, something to respect; and second, a right that can help the person. When someone enters prison, his or her convictions can help him or her. And it is important for us not only because it is a constitutional imposition of the rule of law but also due to a democratic conviction" (Pris2). In a sense, there is a basic consensus on respect for the practice of one's own religion. However, the perspective adopted is one of minimum standards, which has resulted in widespread cross-institutional pragmatic and rather reactive responses to the challenges posed by religious diversity in public institutions. In other words, it is difficult to find a pro-active attitude to accommodating religious diversity, and the religious practices authorised are those considered to not involve too much trouble for the "normal" organisational functioning. This diagnosis is consistent with Zapata-Barrero's (2009, p. 22) observation that the Spanish approach to diversity issues is guided by a "pragmatic 
philosophy" that is not based on a pre-conceived idea but rather on a rights-based, case-by-case approach.

Yet substantial differences between these two types of institutions can be found in their approach to religious diversity. Thus, an account taking into consideration meso-level factors is required. While hospitals tend to differentiate sharply between the domain of the biomedical healing of the body and that of the spiritual care of the soul, prisons seem to have kept religion as just one among their components and services. These different understandings of the role of religion in these two institutions, together with different institutional opportunity structures (Michalowski 2010), have consequences for the accommodation of religious diversity. They lead to quite different institutional responses: while prisons tend to adopt a more accommodating attitude towards the presence of religious diversity, hospitals tend to restrict it.

To account for these similarities and differences, we advocate the need for an explanation that includes both differences in institutional opportunity structures and contextual factors.

First the fieldwork revealed that the specific configuration of the public/private distinction in each institution has implications for the accommodation of religious diversity. In prisons, according to Goffman, there is no distinction between the public and the private spaces in the lives of inmates and thus the institution is responsible for every aspect of their lives. The public and the private are intermingled and the institution becomes the inmates' guardian. Consequently, it is responsible for safeguarding inmates' rights, including the right to religious freedom. Moreover, the walls of the institution are not permeable, leading again to the institution being the main provider of services and the one controlling access to its facilities. This places pressure on the prison to assure that formal procedures to grant religious freedom, such as accreditation for religious actors, are implemented.

On the contrary, in hospitals there is a certain separation between the public and the private spaces of patients' lives. Hospitals are more permeable to the outside world and permit the maintenance of spheres of privacy. This leads to divergent institutional responses. Whereas in prisons the only way to grant the exercise of religious freedom is through institutional involvement, in the case of hospitals the family and the religious community can enter the hospital to satisfy the needs of patients' private lives. In all the hospitals we analysed, religious actors can enter the building as private visitors and this is how most of the patients from religious minorities received religious care. This permeability of the institution to the outside world frees it from the pressure of being in charge of assuring the actual exercise of this right.

A second factor that accounts for the differences found between the responses given by the two institutions is the level of congruence between each institution's function and the role that religion plays in each of them. In the case of prisons the role of religion is perceived as being complementary to the aim of the institution. 
The function of religion in the prison system is, as we have shown above, manifold. On the one hand, religion fills the gaps left by the welfare state in terms of social services, mainly in the transition between the prison and the outside world. On the other, religion is considered to serve the institution's aim, as through their work chaplains enforce the norms of the secular institution in terms of controlling inmates and maintaining order. In a broader sense religion helps restore the social body and thus becomes an important part of the treatment scheme. In other words, religious organisations, as moralising voices in the prison system, are instrumental for the "recovery/restoration" of the functional and healthy social body. The far more evident presence of religion in prisons and its intermingling with institutional dynamics can then be understood in light of its presumed role of re-socialising social deviants. To sum up, religion in prisons is deemed to be adding to the controlling function of the institution and it also fills in the gaps in terms of social services and resources left by the institution.

By contrast, the relation between the religious and rational epistemologies of secular institutions in the context of hospitals is quite different. In this case, rather than complementarity, the relation between religion and medicine is interpreted in terms of competition. This is evident in the fact that hospital staff (mainly doctors) do boundary-work in order to establish and maintain their "epistemic authority" (Lamont / Molnár 2002, p. 179) over religious actors, whom they consider as providing supplementary but not comparable care. This is for example the case with Jehovah's Witnesses and Muslims, whose requests are often seen as competing views on health care issues (even if there is more and more openness to the refusal of blood transfusions) and obstacles (females' refusals to be treated by male gynaecologists) to regular clinical practice and the assumed "aseptic" work of biomedicine. As a consequence of this, the boundaries between the secular and religious spheres remain more visible and tend to be more actively maintained in hospitals than in prisons, where they are more blurred. The existence of a highly corporatist culture among physicians can also help explain the clear distinction between their tasks and the activities of religious actors.

Finally a third factor that facilitates an understanding of the different institutional responses to religious diversity in prisons and hospitals in Spain is to be found beyond the particular attributes of the institutions' opportunity structures. These are the contextual aspects that also mould the way in which each institution addresses religious diversity issues. In the specific case of Spain, the 11 March 2004 bombings in Madrid and the subsequent fear of religious radicalisation in prisons generated a conjuncture in which strong external normative pressure was placed on the penitentiary system. This pressure originating from the government in order to counteract the alleged risk of Islamic radicalisation has led to a series of institutional changes in the prison system regarding religious issues. The main bylaws and regulations addressing religious diversity issues in the Spanish penitentiary system were passed in 2006 and 2007, and 2005 for the penitentiary 
system in Catalonia (the only region with devolved executive penitentiary competences), right after the 2004 terrorist attacks.

Conversely, in hospitals there have not been such external normative pressures, but only non-binding recommendations (i. e. guidelines for the accommodation of religious diversity in hospitals both at the national and Catalan levels) or very general interventions to address social inequalities in health care in which the promotion of religious diversity is not a central issue. Therefore hospitals have experienced less external pressure to respond to religious diversity and, consequently, institutional change in such contexts depends more on internal entrepreneurs/advocates. Nevertheless, the existence of the latter is still infrequent because the number of staff belonging to religious minorities in the Spanish health system is still too small to be a strong lobbying group.

\section{Conclusions}

In this article we have comparatively analysed the institutional responses to religious diversity in Spanish hospitals and prisons. Based on ethnographic fieldwork conducted in eight prisons and six hospitals, we have shown how these two types of institutions both converge and differ in the ways they manage the increasing religious diversification of their populations. They have in common the fact that in general they adopt a rather pragmatic and case-by-case approach. This consists of the provision of minimum-standard responses to the requests made by users, be they the inmates or patients themselves or their families and religious communities. This can be explained by the predominance of a rights-based discourse accompanied by an understanding of minimum standards deriving from the scarcity of specific national regulations.

Yet, despite these common basic characteristics, hospitals and prisons differ substantially in their understanding of religion, which leads to different institutional approaches to religious diversity. Hospitals tend to draw a sharper distinction between the action area of medicine and that of religion, and thus are more reluctant to incorporate changes to respond to religious diversity. They are conceived of as aseptic spaces dominated by the biomedical model, whose aim is to heal the individual material body, relegating religion to the background. However this does not mean the complete absence of religion, and particularly Catholicism, in hospital facilities. Traces from the Catholic past in hospitals along with some small arrangements made to respond to the requests of minorities can be found in some hospitals. In their attempt to restore the social body, prisons provide more room for the intervention of religious actors, mainly Catholic chaplains, but also increasingly the representatives of religious minorities.

These divergent patterns in the responses to the religious diversification of the prison and hospital populations can be explained by taking into account both institutional as well as contextual factors. The specific characteristics and con- 
ditions of each institution (such as the distinction between public and private spaces or the different function attributed to religion) generate different institutional opportunity structures that shape the accommodation of religious diversity. Moreover, particular contextual factors - such as the fear of religious radicalisation in the aftermath of the Madrid bombings - which affect hospitals and prisons unevenly, also account for the disparate actions adopted by these two public institutions to address religious diversity.

Our findings concur with the conclusions of Bowen et al. (2014), who stress the internal variability in the ways states govern religious diversity. Beyond legal regulations and national discourses on the governance of religious diversity, the characteristics and everyday functioning of institutions, together with their contingent surrounding circumstances, shape the specific responses provided by particular organisations. Thus, a meso-level institutional approach, combined with analysis of micro-negotiations, proves fruitful. Future research should consider other factors - such as the different levels of social legitimacy bestowed upon particular kinds of public institutions or the level of professionalisation of institutional staff - that may affect the ways in which different institutions respond to the challenges raised by religious diversity.

\section{Acknowledgements}

We would like to thank Beatriz Aragón, Gloria García-Romeral and Anna Clot for their comments on a previous version of this paper. This research was funded by the Spanish Ministry of Economy and Competitiveness. Julia Martínez-Ariño received the support of the Max-Planck-Institute for the Study of Religious and Ethnic Diversity.

\section{Bibliography}

Acerete, Basilio / Anne Stafford / Pamela Stapleton: 'Spanish healthcare public private partnerships: The "Alzira model",, in: Critical Perspectives on Accounting, 2011/22 (6), 533-549.

Ausín, José Luis: 'La beneficencia pública en la Barcelona de finales del siglo XIX'. in: $X$ Congrés d'Història de Barcelona - Dilemes de La Fi de Segle 1874-1901. 2007, p. 1-12.

Astor, Avi: 'Governing Religious Diversity amid National Redefinition: Muslim Incorporation in Spain', in After Integration. Islam, Conviviality and Contentious Politics in Europe. Wiesbaden 2015, p. 247-65.

Beagan, Brenda. 'L. Neutralizing differences: producing neutral doctors for (almost) neutral patients', in: Social Science \& Medicine, 2000/51 (8), p. 1253-1265.

Becci, Irene / Knobel, Brigitte: 'La diversité religieuse en prison: entre modèles de régulation et émergence de zones grises (Suisse, Italie et Allemagne)', in: Lamine, 
Anne Sophie (eds.): Quand le religieux fait conflit, déscaccords négociations ou arrangements. Rennes 2014, p. 109-121.

Becci, Irene: Imprisioned Religion. Transformtions of Religion during and after Imprisionement in Eastern Germany. England 2012.

Beckford, James A.: 'Prison Chaplaincy in England and Wales - from Anglican Brokerage to a Multi-faith Approach', in: Democracy and Human Rights in Multicultural Societies 2007, p. 267-282.

Beckford, James A.: 'Religious diversity in prisons: chaplaincy and contention', in: Studies in Religion/Sciences Religieuses, 2013, p. 1-16.

Beckford, James A. / Cairns, Ilona. C. M.: 'Muslim prison chaplains in Canada and Britain', in: The Sociological Review, 2015/63 (1), p. 36-56.

Beckford, James / Gilliat-Ray, Sophie. Religion in Prison. Equal rites in a multi-faith society. Cambridge 1998.

Bertossi, Christophe / Bowen, John. R.: 'Practical Schemas, Conjunctures, and Social Locations. Laïcité in French Schools and Hospitals', in: Bowen, John R. / Bertossi, Christophe / Duyvendak, Jan Willem / Krook, Mona Lena (eds.): European States and their Muslim Citizens. New York 2014.

Blau, Peter Michael / Scott, W. Richard: Formal organizations: A comparative approach. Stanford 2013.

Borrell-Carrió, Francesc / Suchman, Anthony L. / Epstein, Ronald M.: 'The biopsychosocial model 25 years later: principles, practice, and scientific inquiry', in: The Annals of Family Medicine, 2004/2 (6), p. 576-582.

Bowen, John R. / Bertossi, Christophe / Duyvendak, Jan Willem / Krook, Mona Lena: 'An Institutional Approach to Framing Muslims in Europe', in: Bowen, John R. I Bertossi, Christophe / Duyvendak, Jan Willem / Krook, Mona Lena (eds.): European States and their Muslim Citizens. New York 2014, p. 1-25.

Burchardt, Marian / Griera, Mar / García-Romeral, Gloria: 'Narrating Liberal Rights and Culture: Muslim Face Veiling, Urban Coexistence and Contention in Spain', in: Journal of Ethnic and Migration Studies, 2015/41 (7), p. 1068-1087.

Cabiedes, Laura / Guillén, Ana: 'Adopting and adapting managed competition: health care reform in Southern Europe', in: Social Science \& Medicine, 2001/52 (8), p. 1205 1217.

Cadge, Wendy: Paging god: Religion in the halls of medicine. Chicago 2012.

Cadge, Wendy / Konieczny, Mary Ellen: "Hidden in Plain Sight": The Significance of Religion and Spirituality in Secular Organizations', in: Sociology of Religion, 2014/75 (4), p. 551-563.

Cadge, Wendy / Sigalow, Emily: 'Negotiating Religious Differences: The Strategies of Interfaith Chaplains in Healthcare', in: Journal for the Scientific Study of Religion, 2013/52 (1), p. 146-158.

Cid, Joseph / Martí, Joel: El proceso de desistimiento de las personas encarceladas. Obstáculos y apoyos. Barcelona 2011.

CIS. Centro de Investigaciones Sociológicas: Barómetro de mayo 2015. 2015, available at: http://www.cis.es/cis/opencm/ES/1_encuestas/estudios/ver.jsp?estudio=14179 [22.07.2015].

Cressey, Donald R: 'Introduction', in: Cressey, Donald R. (ed.): The Prison. Studies in Institutional Organization and Change. New York 1961. 
DiMaggio, Paul J.: 'Interest and agency in institutional theory', in: Institutional Patterns and Organizations: Culture and Environment, 1988/1, p. 3-22.

Finkler, Kaja / Hunter, Cynthia / Iedema, Rick: 'What Is Going on? Ethnography in Hospital Spaces', in: Journal of Contemporary Ethnography, 2008/37 (2), p. 246-250.

Furseth, Inger: 'Secularization and the role of religion in state institutions', in: Social Compass, 2003/50 (2), p. 191-202.

Gallego, Manuel / Cabrera, Pedro José / Ríos, Julian Carlos / Segovia, José Luis: Andar 1 Km en línea recta: La cárcel del siglo XXI que vive el preso. Madrid 2010.

García-Romeral, Gloria / Griera, Mar / Forteza, Maria: 'Gestión de la diversidad religiosa en el ámbito sanitario catalán', in: Inguruak, 2007/43, p. 57-74.

Gilliat-Ray, Sophie: 'From "chapel” to "prayer room": The production, use, and politics of sacred space in public institutions', in: Culture and Religion, 2005/6 (2), p. 287-308.

Gilliat-Ray, Sophie: 'From "Visiting Minister" to "Muslim Chaplain": The Growth of Muslim Chaplaincy in Britain, 1970-2007', in: Barker, Eileen (ed.): The Centrality of Religion in Social Life: Essays in Honour of James A. Beckford. Burlington 2010, p. $145-157$.

Goffman, Erving: Asylums: Essays on the social situation of mental patients and other inmates. 1961a.

Goffman, Erving: 'On the Characteristics of Total Institutions: Staff-Inmate Relations', in: Cressey, Ronald R. (ed.): The Prison. Studies in Institutional Organization and Change. New York 1961b.

Griera, Mar / Clot-Garell, Anna: 'Doing Yoga Behind Bars: A sociological study of the Growth of Holistic Spirituality in Penitentiary Institutions', in: Becci, Irene / Roy, Olivier (eds.): Religious Diversity in European Prisons: Challenges and Implications for Rehabilitation. The Netherlands 2015a.

Griera, Mar / Clot-Garrell, Anna: 'Banal is not Trivial: Visibility, Recognition, and Inequalities between Religious Groups in Prison', in: Journal of Contemporary Religion, 2015b/30 (1), p. 23-37.

Griera, Mar / Martínez-Ariño, Julia: 'The Accommodation of Religious Diversity in Prisons and Hospitals in Spain', in: RECODE Working Papers, 2014/(28), p. 1-13.

INE. Instituto Nacional de Estadística: Estadística del Padrón Continuo. Enero 2015, available at: http://www.ine.es/jaxi/menu.do?type=pcaxis\&path=/t20/e245/p04/pro vi\&file $=$ pcaxis [26.04.2015].

Lamont, Michèle / Molnár, Virág: 'The Study of Boundaries in the Social Sciences', in: Annual Review of Sociology, 2002/28, p. 167-195.

Martínez-Ariño, Julia / García-Romeral, Gloria / Ubasart-González, Gemma / Griera, Mar: 'Demonopolisation and dislocation: (Re-)negotiating the place and role of religion in Spanish prisons', in: Social Compass, 2015/62 (1), p. 3-21.

Martos, Daniel / Devís, José / Sparkes, Andrew C.: 'Deporte entre rejas. ¿Algo más que control social?', in: Revista Internacional de Sociología, 2009/67 (2), p. 391-412.

Michalowski, Ines: 'Explaining the Accommodation of Religious Diversity in the Military: The US and Germany Compared', in: 12th Berlin Roundtables on Transnationality. Berlin 2010.

Michalowski, Ines: 'What is at stake when Muslims join the ranks? An international comparison of military chaplaincy', in: Religion, State and Society, 2015/43 (1), p. 4158. 
Mooney, Graham / Reinarz, Jonathan (eds.): Permeable walls: Historical perspectives on hospital and asylum visiting. Amsterdam - New York 2009.

Pérez-Agote, Alfonso: Cambio religioso en España: los avatares de la secularización. Madrid 2012.

Rostaing, Corinne / Galembert, Claire / Béraud, Céline: 'Des Dieux, des hommes et des objets en prison. Apports heuristiques d'une analyse de la religion par les objets', in: Champ pénal/Penal Field, 2014/11.

Sargent, Carolyn / Erikson, Susan L.: 'Hospitals as Sites of Cultural Confrontation and Integration in France and Germany', in: Bowen, John R. / Bertossi, Christophe / Duyvendak, Jan Willem / Krook, Mona Lena (eds.): European States and their Muslim Citizens. The Impact of Institutions on Perceptions and Boundaries. New York 2014.

Scheper-Hughes, Nancy / Lock, Margaret M.: 'The mindful body: A prolegomenon to future work in medical anthropology', in: Medical Anthropology Quarterly, 1987/1(1), p. 6-41.

SGIP. Secretaria General de Instituciones Penitenciarias. 2015. Estadística penitenciaria. Enero 2015, available at: http://www.institucionpenitenciaria.es/web/portal/documen tos/estadisticas.html [13.04.2015].

Sheikh, Aziz / Gatrad, Abdul Rashid / Sheikh, Usman / Panesar, Sukhmeet Singh / Shafi, Shuja: 'The myth of multifaith chaplaincy: A national survey of hospital chaplaincy departments in England and Wales', in: Diversity in Health and Social Care, 2004/1(2), p. $93-98$.

SNS. Sistema Nacional de Salud. (2015). Estadística de Establecimientos Sanitarios con Régimen de Internad, 2015, available at: http://Pestadistico.Inteligenciadegestion. Msssi.Es/Publicosns/Comun/Defaultpublico.Aspx [07.07.2015].

Street, Alice / Coleman, Simon: 'Introduction: Real and Imagined Spaces', in: Space and Culture, 2012/15 (1), p. 4-17.

Sullivan, Winnifred Fallers: A ministry of presence: Chaplaincy, spiritual care, and the law. Chicago 2014.

Todd, Andrew J.: 'Religion, Security, Rights, the Individual and Rates of Exchange: Religion in Negotiation with British Public Policy in Prisons and the Military', in: International Journal of Politics, Culture, and Society, 2015/28 (1), p. 37-50.

Van der Geest, Sjaak / Finkler, Kaja: 'Hospital Ethnography: Introduction', in: Social Science \& Medicine, 2004/59 (10), p. 1995-2001.

Zapata-Barrero, Ricard: ‘¿Existe un enfoque propio de gestión de la inmigración? Filosofía práctica de la política de gobernabilidad en España', in: Políticas y gobernabilidad de la inmigración en España. Barcelona 2009, p. 21-31.

Zucker, Lynne G.: 'Institutional Theories of Organization', in: Annual Review of Sociology, 1987/13, p. 443-464. 


\section{Interviews cited}

Hosp1. High rank official, public health system (31/05/2012).

Hosp2. Delegate for hospital pastoral care and hospital chaplain (23/12/2011).

Hosp3. Hospital intermediate manager (07/09/2012).

Hosp4. Hospital Protestant visiting minister and regional councilor for welfare of the Protestant Council.

Pris1. High rank official, penitentiary administration (19/10/2011).

Pris2. Civil servant, penitentiary administration (31/01/2012).

Pris3. Prison director (05/03/2012).

Pris4. Prison director (18/04/2012).

Pris5. Prison Catholic chaplain (19/12/2011).

Pris6. Prison Reiki teacher (08/07/2013). 